I have yet to see undoubted specimens of C. coturnix from Japan. Of course, that proves nothing, for Mr. Ogilvie-Grant may have seen them, but with his paper and the above-described series of specimens before me I can only say in regard to the occurrence of the two species in Japan "not proven."

Concerning the exact significance of the elongated throat feathers in the eastern birds, I have no well-founded theory to offer, but it seems to me as if there might be only a strong tendency toward the development of a "beard" in the eastern form, with an individual variation in this respect similar to the throat coloration.

It will probably remain for the Japanese field ornithologists to settle this question by the study of large series of fresh birds.

$I$ hope that the above remarks may help them to fully understand the issue and consequently to collect intelligently.

Proc. N. M. $93-49$ 



\title{
NOTES ON BIRDS OF CENTRAL MEXICO, WITH DESCRIPTIONS OF FORMS BELIEVED TO BE NEW.
}

\author{
BY \\ P. L. Jouy.
}

The following notes on the birds of central Mexico are the result of about twelve months' travel in that interesting country. Landing at Tampico on the 13th of October, 1891, a few days were spent in vigorous battle with mosquitoes and in courteous intercourse with the custodians of the custom house, who, thanks to the kindness of Señor Don Mateo Romero, passed all my luggage and collecting outfit through without examination. Few birds were seen, the only species worthy of mention being Corvus mexicanus and Milvulus forficatus, which were not observed at any other place. A deep narrow river empties into the Gulf at Tampico, giving access to the interior of the country by means of native dugout canoes. I was strongly advised by the United States vice-consul, Mr. Presley, to make the trip some 40 or 50 miles up the river, but fear of malaria and possibly "yellow jack" drove me to seek a safer climate. I was assured that it was perfectly safe to spend the winter months, that is from October to March, in the hot country by using ordinary precautions in regard to diet and drink. By working up and down the railroad considerable country could be covered with little loss of time.

Eighteen hours by the Mexican Central Railroad brings the traveler through the tropies, where nature is most luxuriant, up through cooler regions, across dashing mountain streams, through magnificent gorges, and, finally, across arid plains to the city of San Luis Potosi, the capital of the State of the same name. This, one of the largest and most important cities of Mexico, has unrivaled railroad facilities, being on the direct line of the Mexican National Road, running north and south, and is the western terminus of the Tampico branch of the Mexican Central. It also connects with the west by means of the Aguas Calientes branch of the Mexican Central. It is thus easy to reach the surrounding country, and, although the immediate neighborhood of the eity is uninviting, yet an hour's travel in almost any direction takes the traveler into sparsely-wooded or hilly country, where collecting is possible.

Having paid my respects to the governor, Gen. Don Carlos Diez Gutierrez, and presented my letters and eredentials, I received, through 
his kindness, a general letter of introduction from him to all officials and others in the State, which proved of great service to me.*

From the eity of San Luis, therefore, as headquarters, a number of trips were made from time to time. One to Chareas, in the northern part of the State, established the habitat of Aphelocoma cyanotis. Through the courtesy of Señor Don Xavier Espinosa, I was enabled to visit the hacienda Angostura, belonging to his family, which lies near the station of San Bartolo on the Tampico Line; here a new form of Basileuterus rufifrons was obtained, together with other varieties. Grus mexicana was here numerous in December. Several species not elsewhere obtained were collected at Solidad Don Carlos, a suburb of San Luis; also at Ahualuleo, a station 24 miles from the city on the Aguas Calientes branch. Before leaving San Luis a trip was made to Lake Patzcuaro, in Michoacan, where fresh specimens of that interesting bird, the Mexican Jaçana, were obtained and forwarded to Washington, where they were mounted into a striking group for the U. S. National Museum Exhibit at the World's Columbian Exposition.

From January 9 to July 12, 1892, was spent in or near the eity of Guadalajara, from whence numerous expeditions were made into the country. The Barranca Ibarra, a favorite collecting ground, lay about half a day's journey north of the city. This beautiful gorge, descending abruptly 1,500 feet, gave access to a quite varied and tropical fauna and flora. Here grew and were cultivated the pineapple, banana, and the mango; and here also the coffee plant flourished; many species of birds found here were never seen on the plateau above, and collecting would have been ideal if some of the tropical insect pests had not also entered into this paradise.

Other trips made from Guadalajara were to the falls of Juanacatlan, the "Niagara of Mexico," to Lake Chapala, reached from the station Atequiza, where I found unaccountably poor collecting, and also to the hacienda El Molino, which I visited through the kindness of Señor Don José Maria Negrete. This place, reached from the station Negrete, is probably the best locality for the naturalist near Guadalajara. A large, semi-wild garden planted with a great variety of trees and shrubs, and well watered by means of irrigating ditches, proved to be a great attraction for birds of all kinds. The proprietor, a gentleman who had traveled in nearly all lands, was also a great lover of birds, and kept several magnificent living specimens of the rare Grus americana, said to have been taken in the country, as an ornamental feature of his place.

In the latter part of March a trip was made on horseback south of

\footnotetext{
* In no country are letters of introduction more valuable than in Mexico. The proximity to our wildest borders and the ease of ingress has flooded the country with the worst varieties of tramps and adventurers, until the oft-deluded native has come to regard all foreigners with suspicion. The traveler intending to spend any length of time in Mexico will, therefore, do well to provide himself with credentials.
} 
Guadalajara, through the town of Zapatlan, to a place known as San Marcos, in the southern part of the State of Jalisco, and on the east base of the volcano of Colima. In this locality and in the neighboring Barranca Veltran (or "Beltran," as it is commonly known), a num. ber of species were seen for the first time.

These barrancas, or gorges, produced either by ages of erosion or else by volcanic agency, are often a mile, more or less, deep, and perhaps 3 or 4 miles across in places, narrowing down to the width of a small stream at the bottom; they are therefore rather precipitous, and as they lie in the direct line of travel they give scope for the engineer's abilities. The change from the comparatively barren plateau to tropical luxuriance is often so great that the effect is that of entering into one of nature's greenhouses, a grand forcing house, a score or more miles in length, sheltering: what unknown treasuries for the botanist and zoölogist! Here are found such birds as Dendrornis, Engyptila, Conurus, and Amazona, besides numerous hummers and other tropical forms.

A few species are included in this list which were collected at Guaymas, on the Gulf of California, and also a few from the mountains in Sonora, 32 miles south of the border town of Nogales, notably Parus wollweberi, Dendoica gracice, Columba fasciata, and Cyanocitta macrolapha.

It will be seen from the foregoing that most of the species enumerated are from the temperate table-land region most nearly corresponding to our own southern borders of Arizona and New Mexico and although many common tropical birds will be looked for in vain in this list, yet it is hoped that it will not prove the less valuable on that account.

Color notes of the iris and other soft and fading parts of specimens have in all cases been compared with the plates in Ridgway's Nomenclature of Colors, which is an indispensable companion of the field naturalist, and is likewise invaluable in determining the tints of feathers. I am also much indebted to the author for advice and aid in the identification of species. In conclusion, I take pleasure in acknowledging the extreme courtesy received from the officials of the Mexican Government in all parts of the country, who did everything in their power to further my objects. Through the interest of Señor Mariseal, at the request of Minister Ryan, I received an autograph letter from his excellency President Porfirio Diaz, introducing me to the favorable notice of the governors of all the provinces of Mexico. These gentlemen in turn, so far as I traveled, gave me letters current in their respective States, which did much to facilitate traveling in the country.

\section{Family TURDDA.}

1. Catharus melpomene clarus, subsp. nov.

A comparison of two adult male birds from Jaliseo with a series from Vera Cruz and Gutemala shows that the western bird is a clearly rec. 
ognizable geographical race. It is a slightly larger and very much paler bird than the eastern form and has decidedly longer wings and tail. It may be recognized by the following description:

Catharus melpomene clarus, subsp. nov. Type, U. S. National Museum, No. 126627, o ad. Barranca Ibarra, Jalisco, W. Mexico, May 13, 1892, P. L. Jouy, coll.

Above, head and back olive-brown, rump tawny-olive, tail slightly darker, wings tawny-olive, the inner webs of the primaries and secondaries abruptly dusky; the center of the under surface of the wings cream-buff (clay-color in melpomene). Breast and flanks pale olive-gray; throat, belly, and crissum pure white; a few feathers of the sides of the crissum tinted pale isabella-color.

Dimensions: Length (fresh specimen), $173^{\mathrm{mm}}$; wing, 86 ; tail, 74 ; tarsus, 33. Iris very dark brown; eyelids, angle of mouth, and inside of mouth, cadmium-orange; tarsi and toes pale yellow.

A very shy, elusive species, always found on or near the ground in deep shady woods.

This clearly marked form has apparently escaped the notice of both collectors and writers, as I find no mention of Catharus melpomene as a western Mexican bird, nor has a paler race been referred to by authors. As Prof. Baird has pointed out in Review of American Birds, page 7, Costa Rican specimens differ from east Mexican and Guatemalan examples in "the prevalence of a grayish olive shade in the back;" they are also a deeper, clearer gray on the breast and flanks, and average shorter tails. A larger series of specimens in spring plumage would probably show it to be a distinct race.

\section{Merula tristis Swains.}

A common bird in the Barranca Ibarra, near Guadalajara. Specimens taken March 9 and April 21. Only note heard was a single sharp chirp or alarm note.

Iris dark brown.

\section{Myadestes obscurus occidentalis Stejn.}

San Marcos, southern Jalisco, March 25.

This bird, popularly known as the clarin, is a familiar and highly prized cage bird all through the interior of Mexico. The finest clarins are said to come from the eastern part of the country from the State of Vera Cruz southward, M. unicolor being more highly prized as a singer than M. obscurus.

The song of this bird, impossible to deseribe, has the most sylvan character of any bird music I am acquainted with. It is the very essence of deep shady woods and falling water. Poured forth suddenly, it has a surprising tinkling metallic quality, mingled with flute-like warbling notes given in falling eadences. The song is not loud nor is it long sustained, but it has a character all its own. 
The color characters given by Dr. Stejneger in Proc. U. S. N. M., IV, 1882, page 371, separating var. occidentalis and var. insularis from $M$. obscurus are shown by this specimen to be untenable, it having white tips to all the tail feathers, and also light edges to the tips of the innermost secondaries. The wing formula of the three birds, however, appears to be distinct. My specimen agrees with the type of occidentalis in having the forehead white.

\section{Sialia mexicana Swains.}

Taken in foothills, 25 miles west of Charcas, San Luis Potosi, in November. Common in the valleys at that time and in the mountains up to an elevation of 7,000 feet.

Iris dark brown.

\section{Family MIMID E.}

\section{Melanotis cærulescens (Swains.).}

Taken in Barranca Ibarra, near Guadalajara, in March and April.

This bird, known as the Mulato by the Mexicans, is a very commoii cage bird all over the country. It is a very fair singer and mimie, and is much valued for its lively and familiar ways.

Iris deep reddish-brown.

\section{Harporhynchus curvirostris (Swains.).}

A very common species in the central part of the State of San Luis Potosi: it was taken at Ahualulco in October, and was found abundant in the valleys about Charcas in November. It seemed to be found exclusively in the valleys grown up with Opuntias, in the larger specimens of which it builds its nest. Iris chrome; upper mandible, dusky; under mandible, pale yellow; tarsi, pale yellowish; toes, dusky.

\section{Harporhynchus longirostris (Lafr.).}

Taken at hacienda Angostura, in southern part of State of San Luis Potosi, in December. Rather a shy bird and apparently not very common, as few specimens were seen.

Iris cadmium-orange.

Family SYLVIID $Æ$.

8. Regulus calendula (Linn.).

A single specimen was taken at Soledad, San Luis Potosi, on November 27 , but was apparently not at all common. Not seen elsewhere.

\section{Polioptila cærulea obscura Ridgw.}

Taken in the neighborhood of Guaymas in February. 


\section{Family PARIDA.}

10. Psaltriparus melanotis iulus, subsp. nov.

SUBSP. CHAR.-Differing from true $P$. melanotis in having the back hair brown instead of "yellowish brown" (bistre); paler under parts, the ventral region being only very slightly tinged with buffy; bill larger and heavier but other dimensions apparently the same.

Навгтат.-Western Mexico (type No. 126630 U.S. National Museum, o ad., Hacienda El Molino, Jalisco, June 15, 1892; P. L. Jouy).

An example from Guanajuato, collected by Prof. A. Dugès, agrees fairly well with the type except that being a very young bird it is darker above and has buff edgings to the wing's and tail. The flanks are also tinged with vinaceous.

This form is apparently interfodiate between $P$. melanotis and $P$. lloydi but is easily distinguished from the latter by its distinctly gray head and light, hair-brown, back. The dimensions of the bill are about the same.

\section{Parus wollweberi (Bonap.).}

Adult and young of this bird were taken at an elevation of 6,000 feet in the mountains, 32 miles south of Nogales in Sonora, June 18. They were in small flocks with full-grown young which they were tending very solicitously.

Bill lavender at the base, tip dusky, edges pale yellow; gape yellow ; tarsi and toes lead color.

\section{Family SITTIDA.}

\section{Sitta carolinensis aculeata (Cass.).}

Taken 32 miles south of Nogales in Sonora, June 19, in the pines.

\section{Family CERTHIIDA.}

13. Certhia familiaris mexicana (Glog.).

Seen in the pines 32 miles south of Nogales, Sonora, June 19.

\section{Family TROGLODYTIDA.}

\section{Heleodytes brunneicapillus (Lafr.).}

Common everywhere in the arid plain region wherever the cactus is abundant. Taken at Ahualuleo, near San Luis Potosi, in October, and found abundantly in suitable places in Jalisco. Its loud purring notes proclaiming its presence unmistakably wherever found. In habits this great wren acts more like one of the Harporhynchi, than one of its relatives. It builds its nest in the cactus (Opuntia), like Harporhynchus 
curvirostris, and I have never seen it cock its tail over the back in the characteristic wren attitude.

15. Thryophilus sinaloa Baird.

This is the commonest species of wren at the Barranca Ibarra. Jaliseo, where it was taken May 13. It affects deep, shady woods, and breeds in the thickets bordering the stream which flows at the bottom of the barrauca. Iris burnt-sienna; under mandible lilaceous; tarsi and toes, lilac-brown.

Family MNIOTILTID A.

16. Helminthophila celata (Say).

Common in the latter part of November at Soledad, San Luis Potosi.

17. Dendroica virens (Gmel.).

Common in Cuernavaca, Morelos, in September; specimen $\operatorname{ta}^{17}$ en September 14.

18. Dendroica auduboni (Towns.).

Very common all winter about Guadalajara. Familiarly seen in the gardens and about the court-yards of the houses, searching for insects in the crevices of walls and among the plants.

19. Dendroica dominica albilora Baird.

Taken in Cuernavaca, Morelos, September 4.

20. Dendroica graciæ Coues.

Quite common in mountains 32 miles south of Nogales, Sonora. Specimens taken June 17. Exceedingly shy, keeping high up in the pines.

21. Dendroica æstiva sonorana Brewster.

Common in Cuernavaca, Morelos, in August and September. Specimen taken August 19.

22. Sylvania pusilla pileolata (Pall.).

Taken at the falls of Juanacatlan, Jalisco, January 31. Common in the willows near the banks of streams.

\section{Basileuterus rufifrons jouyi Ridgway.}

[Proc. U. S. Nat. Mus., xv, p. 119.]

Two specimens, male and female, of this new form were taken at the Hacienda Angostura, December 8. These were first seen in bushes overhanging a small stream. They had the quick, nervous movements of a Geothlypis, and uttered scolding notes when disturbed. Another specimen collected at the Barranca Ibana, Jalisco, May 11, is identical 
in color with the type specimen. These versatile littie birds seem to be of varying habits, and are found in all suitable places affected by warblers. Never found far from running water, they may be seen dodging in and out among the bushes on the banks of streams, or on the shady side of a barranca they will be seen gleaning a harvest of small game in the treetops.

\section{Euthlypis lachrymosa (Bonap.).}

Tolerably common in the Barranca Ibarra where it undoubtedly breeds. Specimen taken May 14. Of very shy, skulking habits, this bird is almost invariably found on or near the ground. Delighting, like a water-thrush, in shaded thickets near running streams, it affects boggy places and is very expert in dodging behind bushes when disturbed. It has the constant habit, when walking on the ground, of flirting the tail sideways.

\section{Family VIREONID A.}

\section{Vireo flavoviridis (Cass.).}

Tolerably common in the Barranca Ibarra in May, where it was undoubtedly breeding.

Iris pale venetian-red; bill and feet plumbeous.

26. Vireo noveboracensis (Gmel.).

Taken at the Hacienda Angostura, San Luis Potosi, December 16. Iris, white.

\section{Family LANIID E.}

27. Lanius ludovicianus excubitorides (Swains.).

Exceedingly common and abundant everywhere in the central plateau region. Taken at Soledad, near San Luis Potosi, in December. Fond of perching in a conspicuous place, it has taken kindly to the telegraph wires and may almost invariably be found on them. A nest seen on the border at Nogales on June 2 contained five eggs. It was placed in the center of a mesquite tree and about 6 feet from the ground. The nest was so loosely put together and so tangled in the thorny growth of the tree that it could not be lifted out. It was composed of coarse grasses and sticks and lined with finer grasses and thickly and softly padded with the dried flowers of the amaranth.

\section{Family TANAGRIDA.}

\section{Euphonia, sp.}

A single specimen of one of these small birds was seen in the Barranca Ibarra, but could not be identified. It was dark metallic blue on the back and bright yellow on the under parts. It was only seen for a moment and then disappeared and was not observed again. 
29. Piranga hepatica Swains.

Barranca Ibarra, near Guadalajara, March 10. Several specimens seen.

30. Piranga bidentata Swains.

An adult male was taken in the Barranca Ibarra, near Guadalajara, May 14. This is probably near its most northern range, and no other specimens were seen.

\section{Family FRINGILLID $A$.}

31. Cardinalis cardinalis canicaudus Chapm.

Hacienda Angostura, San Luis Potosi, in December. Common in all suitable cover.

32. Pyrrhuloxia sinuata Bonap.

Collected at Ahualulco, in San Luis Potosi, October 28, but apparently not very common.

33. Guiraca cærulea eurhyncha Coues.

A common species throughout the central plateau region of Mexico; it was taken at the Hacienda Angostura, San Luis Potosi, in December, and was also found quite abundant in Jalisco. Iris, dark brown; upper mandible, dusky; lower mandible, dull lead-color.

34. Sporophila torqueolà (Bonap.).

Apparently not very common. A pair were seen and taken at the Hacienda El Molino, Jalisco, June 12.

35. Passerina versicolor (Bonap.).

Taken at the Barranca Ibarra, March 10.

36. Amphispiza bilineata (Cass.).

Abundant in the hills near Guaymas in February.

37. Zonotrichia leucophrys intermedia Ridgw.

Fields and hedges around San Luis Potosi, November 20, abundant.

38. Spizella breweri Cass.

Abundant in small flocks in the fields among low bushes. Falls of Juanacatlan, Jalisco, January 31.

39. Junco cinereus (Swains.).

Quite abundant in small flocks in the mountains 25 miles west of Charcas, San Luis Potosi, at an elevation of 7,000 to 8,000 feet. Specimens taken November 13. They were found on the open sunny slopes of the mountains, feeding on the ground or in low serubby growth. 
Iris, chrome; upper mandible, dusky; under mandible, pale yellow; tarsi, pale yellowish; toes, dusky.

\section{Pipilo fuscus Swains.}

This is one of the commonest birds everywhere in central Mexico. Almost invariably found on the ground, or on low walls, in tangled, grassy places; it is particularly partial to hedges along the roadsides. Of familiar and inquisitive disposition, it is constantly intruding itself on the passer-by. Utilizing the runways of the ground squirrels it keeps dodging in and out, appearing and disappearing, to the confusion of the collector. Taken at Ahualulco and San Luis Potosi, October 28 and November 30.

\section{Pyrgisoma rubricatum (Licht.).}

Only seen at the Barranca Ibarra, near Guadalajara, May 11 and 13. This is essentially a ground species, and, although it was not exactly rare, it is a very shy bird and difficult to get. It was found almost exclusively around the head of the barranca on the bare hillsides and on the road leading down, but never descending any distance toward the warmer lower country.

Iris, reddish brown; tarsi and toes, pale brownish lilaceous.

\section{Carpodacus cassini Baird.}

Abundant in small flocks among the live oaks at an elevation of 7,000 to 8,000 feet. In the mountains 25 miles west of Chareas, San Luis Potosi, November 13.

\section{Spinus psaltria mexicanus (Swains.).}

First seen at Soledad, San Luis Potosi, November 27, in small flocks in cottonwood trees, also taken at the Hacienda El Moïino, in Jalisco, June 13. This is the large form first described by Swainson from the table-land of Mexico, Real del Monte, and which ranges north to southern Texas. Average measurements of six specimens of this bird from southern Texas and northern Mexico give the following results: Wing, 2.60 inches; tail, 1.70 ; culmen, 0.40 . Two other forms, appa ently distinct and with different habitats, have been called mexicanus by various authors, but can readily be distinguished by their smaller size and the more brilliant coloring of the under parts. They may be distinguished as follows:

\footnotetext{
Spinus psaltria croceus, subsp. nov.
}

SUBSP. CHAR.-Differing from S. mexicanus in having the entire under parts a deep gamboge-yellow instead of pale eanary-yellow; the white of the wing at the base of the primaries more restricted, and with less white on the tertials. Axillaries mainly jet black (axillaries gray, or gray narrowly streaked with black in mexicanus). Size smaller, average of four specimens from Costa Rica, Guatemala, and Panama give, for the wing, 2.42 inches; tail, 1.52 ; culmen, 0.37 .

Habitat.-Western Central America (type No. 53,839 U. S. National Museum, $\delta$ ad., Panama, J. McLeannan. 
Spinus, species.

The species inhabiting the Peninsula of Yucatan resembles croceus very closely in size and general coloration, but has the axillaries bright yellow with black bases. This may prove to be a distinct form, but the absence of reliable material from that locality prevents me from arriving at any conclusion in regard to it.

\section{Family ICTERID $Æ$.}

44. Icterus abeillei (Less.).

Two adult males of this species were taken Jume 10 and 12 at the Hacienda El Molino, Jalisco. They were apparently not very common and the female escaped notice.

\section{Icterus wagleri Scl.}

Two adult males taken in Barranca Ibarra, Jalisco, April 20, 22.

Iris dark brown; base of under mandible lead color; tarsi and toes dusky olive.

\section{Icterus audubonii Giraud.}

Two adult females taken at the Hacienda Angostura in San Luis Potosi, December 10 and 16.

\section{Icterus cucullatus Swains.}

One specimen, a young male, taken in the Barranca Ibarra, April 21.

48. Icterus pustulatus (Wagl.).

Taken in Barranca Ibarra, Jalisco, April 21.

49. Sturnella magna neglecta (Aud.).

Abundant in the salty meadows of southern Jalisco. Specimens seen seemed very pale in color.

\section{Quiscalus macrourus Swains.}

Taken at Saledad, near San Luis Potosi, November 30. Iris light yellow. Very abundant all through the central Mexican region. A noisy and familiar bird, it makes itself at home in all cultivated places, and is particularly abundant in the parks and gardens of the cities. It even invades the patios of the houses and steals the food from the domestic fowls.

\section{Family CORVID E.}

51. Cyanocitta stelleri macrolopha (Baird).

Abundant in the mountains south of Nogales in Sonora. Frequenting the pine woods in small flocks, they are very noisy birds, cawing all the time, and moving about from place to place continually.

52. Aphelocoma cyanotis Ridgw.

This bird first described by Mr. Ridgway in his "Manual of North American Birds" from a very old specimen collected by John Taylor, 
esq., in 1836, and labeled simply "Mexico," was taken in the mountains, 25 miles west of Charcas, San Luis Potosi, November 13. It was found tolerably abundant in small flocks among the live oaks at an elevation of 7,000 to 8,000 feet. Found in rather open sparsely-covered situations, it seemed to spend much of its time on the ground feeding on fallen acorns, its habits resembling the Arizona jay, and, like that species, it also has a rather weak voice.

\section{Calocitta colliei (Vig.).}

Only seen at the Barranca Ibarra, where specimens were collected Mareh 9. This noisy, showy species was found in the lower sides of the barranca in small flocks of four or five. Very shy and wary and constantly on the wing, flying from place to place, they make the air ring with their loud, harsh cries.

There seems to be considerable difference in size between the sexes of this bird, the male being larger in every way. The crest of the male also difters from the female's in being longer, recurved, and tipped with white, while the female's is straight and tipped with blue.

\section{Corvus mexicanus Gm.}

This species, long supposed to be restricted to the west coast of Mexico, notably at San Blas and Mazatlan,* was taken near the gulf coast at Tampico, October 15 , thus apparently extending the range of the bird clear across the country. Several specimens were seen in company with grackles (Quiscalus macrourus) feeding in a plowed field. Seen from a distance their glossy plumage corresponded so closely with that of the grackles that, at first sight, it was difficult to tell the two birds apart; of course closer inspection revealed their different proportions, but I believe that this circumstance, if it is a constant habit, of the crows being found in company with the grackles may have led to their being overlooked by collectors.

I did not observe this bird elsewhere, but I have no doubt that further investigations will show that the species has a much larger range than has been credited to it heretofore.

\section{Family TYRANNID $\AA$.}

55. Sayornís nigricans (Swains.).

Very common in state of Jalisco in summer.

56. Pitangus derbianus (Kaup).

Abundant in the cottonwood trees in the outskirts of Guadalajara; its noisy, querulous notes were constantly heard. Taken at Agua Azul, Guadalajara, February 4.

Iris dark brown.

*Biologia Centrali-Americana, Aves, Vol. I, p. 488. 
57. Megarhynchus pitangua (Linn.).

Barranca Veltran, southern Jalisco, March 24. Common in the tree tops at the bottom of the barranca. Not taken elsewhere.

Iris very dark brown.

58. Pyrocephalus rubineus mexicanus (Scl.).

Abundant everywhere in the arid valleys of Mexico, this bird is one of the most familiar and well known forms. Its brilliant color and showy habit of darting into the air render it very conspicuous wherever found. Taken 15 miles west of Chicas, in the state of San Luis Potosi, November 13.

59. Empidonax griseus Brewst.

Taken at Soledad, near San Luis Potosi, December 3.

60. Empidonax hammondii (Xantus).

Taken at the Barranca Ibarra, Jalisco, March 9.

61. Empidonax wrightii Baird.

Taken at Soledad, near San Luis Potosi, November 20; also at the Barranca Ibarra, Jalisco, March 9.

62. Myiarchus mexicanus magister Ridgw.

Common in cottonwood trees along river bottoms. Taken at Hacienda El Molino, Jalisco, June 10.

63. Myiarchus lawrencii olivascens Ridgw.

Barranca Ibarra, Jalisco, May 14.

64. Milvulus forficatus (Gmel.).

A single specimen of this bird was shot at Tampico, October 15. It was perched on a telegraph wire, and seemed to be very unsuspicious. It was not seen in any other locality.

Iris dark brown.

\section{Family COTINGID $\mathbb{E}$.}

65. Platypsaris albiventris (Lawr.).

A shy, silent species found in the tree tops. Of rather sluggish habits, they present a rather striking contrast to the vivacity of the fly-catcher. Only observed in the Barranca Ibarra, where a specimen was obtained May 13. Iris umber brown; bill and feet lead color. 


\section{Family DENDROCOLAPTIDA.}

66. Dendrornis mentalis Baird.

Only met with at the Barranca Veltran, southern Jalisco, where it is apparently not very common, as only one specimen was seen. This was taken March 24.

Iris dark brown; upper mandible dusky olivaceous, under mandible lilaceous; tarsi and toes olive.

\section{Family TROCHILIDA.}

67. Cœligena clemenciæ Less.

Taken at Cuernavaca, Morelos, September 24.

68. Trochilus colubris Linn.

Very abundant at Cuernavaca, Morelos, during the whole of September.

69. Cyanomyia ellioti (Berl.).

A common species in the vicinity of Guadalajara; they were taken at Lake Chapala, February 19, and were found quite abundant at the Barranca Ibarra, where specimens were collected in March. A female from Chapala has the throat stained a dirty yellow from contact with the pollen of some plant. These specimens appear to differ from violiceps in having a longer and broader bill, as well as having a shining green tail instead of bronzy red, as in the latter species.

70. Cyanomyia violiceps Gould.

This species was quite abundant in Cuernavaca, Morelos, from the latter part of August to the first week in September, during which time quite a number of specimens were taken.

71. Amazilia beryllina (Licht.).

Taken at Cuernavaca, Morelos, September 3. Apparently not very common.

72. Iache latirostris (Swains.).

Taken at Hacienda Angostura, San Luis Potosi, December 10; also at the Barranca Ibarro, Jalisco, March 10, where it was a common species. Base of bill carmine.

73. Chlorostilbon auriceps Gould.

Two specimens of this rather rare species were taken at San Marcos, southern Jalisco, March 25. Other specimens seen at about the same time would indicate that this locality, the base of the volcano of Colima, was the proper habitat of the species. 
Family CAPRIMULGIDA.

74. Chordeiles texensis Lawr.

Very common at Lake Patzcuaro, December 22, flying low over the water at dusk. Not observed elsewhere.

Family PICID A.

75. Dryobates scalaris bairdi (Scl.).

Taken at Ahualulco, near San Luis Potosi, October 28. Apparently not very common, as a single pair only were seen. Not seen elsewhere.

76. Sphyrapicus varius (Linn.).

Very abundant near San Luis Potosi in November and December. Taken at Soledad November 30 and December 3.

77. Melanerpes aurifrons (Wagl.).

Very abundant in the State of San Luis Potosi, where it was taken at Ahualulco and Soledad, in October and November, and also at the Hacienda Angostura, in the eastern part of the State, in December.

78. Melanerpes uropygialis (Baird).

Taken in the Barranca Ibarra, May 14.

\section{Family MOMOTID五.}

79. Momotus mexicanus Swains.

San Mareos, suntheru Jaliseo, March 29. Only seen at one place, a tangled thicket near a small stream. They did not seem at all shy, but sat on a low branch of a tree and eyed one with mild curiosity, all the while uttering a soft, low note. A singular characteristic noticed was the prominence of the ear tufts, which in this species project, in life, from the sides of the head very conspicuously, and give the bird a very unusual and grotesque appearance.

Iris dull carmine.

\section{Family ALCEDINIDA.}

80. Ceryle americana septentrionalis Sharpe.

Very common on the borders of the lakes and all small streams throughout the country. Specimens taken at Hacienda Angostura, San Luis Potosi, and at Lake Chapala, Jalisco.

Family TROGONID A.

81. Trogon ambiguus Gould.

Taken in pine woods at Agosto, en route from San Marcos to Atenquiqui, April 1. A few were seen at this place in the pine woods, where Proc. N. M. $93-50$ 
they were very shy; also occasionally seen at the Barranca Ibarra. Iris very dark brown, eyelids orange; bill bright yellow.

\section{Family CUCULID E.}

\section{Crotophaga sulcirostris Swains.}

Common in thickets in small flocks near Lake Chapala, Jalisco, in February.

\section{Piaya mexicana Swains.}

Taken at the Falls of Juanacatlan Jalisco, January 31, and the Barranca Ibarra, April 20. For such a large, showy bird, this is an exceedingly unsuspicious one. It is easily approached, and in fact seems to be unconscious of danger even after its mate has been killed. It has a note resembling that of a small woodpecker.

Iris carmine or crimson; bill apple green, slightly dusky at the base; inside of mouth blue-black; tarsi and toes plumbeous.

\section{Family PSITTACIDA.}

\section{Ara militaris (Linn.).}

Tolerably common at the Barranca Veltran, southern Jalisco; also found in the pine forests of Agosto. I was told that it had been taken as far north as Guadalajara, at the Barranca Ibarra, but I did not see it at that locality. This bird joins in the noisy evening flights of the parrots, flying very high and uttering piercing cries.

Iris yellow; naked skin around the eye carmine.

\section{Conurus petzii (Wagl.).}

Common in small flocks in the Barranca Veltran, southern Jalisco, but not met with elsewhere. Specimen taken March 24 .

These birds readily become domesticated, and are familiar pets with the natives. They are seldom caged, except at night for protection, and soon learn to distinguish their master and to say a few words.

Iris naples yellow; naked skin around eye king's yellow; upper mandible flesh-tinted, sides of lower mandible dusky, middle portion horn color.

\section{Amazona finschi (Scl.).}

This is the most abundant species of the family found in southern Jalisco. Common in the Barranca Veltran, where specimens were taken March 24 and 27. During the day these birds are seattered in small flocks all over the country, feeding on the various wild fruits, but toward evening they assemble in flocks of thirty or more and seem to take delight in long flights up and down the barranca, screaming in noisy chorus all the while. Suddenly they swerve off their course and alight in a large tree and for a few moments all is silent, when, appar- 
ently without cause, they fly forth and seek some other tree, only to repeat the performance which they keep up until darkness sends them to their final roosting place. Ordinarily stupid and easily approached, they seem to be unusually suspicious at nightfall and occasionally fly quite high, when their rapid powerful flight much resembles that of a wild duck. Inner ring of iris brown-ocher, central portion chrome, outer edge, orange; bill pale yellow, brightest on sides of upper mandible; naked skin around eye dusky lead color; toes lead color; nails dusky.

\section{Family STRIGID A.}

87. Strix pratincola Bonap.

Specimen shot in a cultivated field at noontime. It had probably been disturbed at its roosting place and seemed to be in a dazed condition, and was easily approached.

Taken at Agua Azul, Guadalajara, February 4.

Iris very dark brown.

\section{Family BUBONID A.}

88. Bubo virginianus subarcticus (Hoy).

Specimen taken in Guadalajara, May 30.

89. Speotyto cunicularia hypogæa (Bonap.).

A few specimens were seen in the State of San Luis Potosi, at the Hacienda $\Lambda$ ngostura. Their mounds were spread over a considerable portion of a barren plain, and although the weather was stormy and unauspicious, being in December, as soon as the sun came out they were seen standing on top of their little mounds, bowing gravely as one approached.

\section{Family FALCONIDA.}

90. Circus hudsonius (Linn.).

A common species in central Mexico. Specimen taken at Soledad, San Luis Potosi, November 27.

\section{Buteo borealis calurus (Cass.).}

Exceedingly abundant through the whole central region.

92. Urubitinga anthracina (Licht.).

This bird has a peculiarly heavy awkward flight and seems to be very stupid in comparison with other hawks. It has also a most peculiar voice. I was attracted from quite a distance by a curious harsh squawk which I at first took to be the note of a night-heron; following up the sound my surprise was great to see a large dark-colored hawk perched 
on the branch of a tree and uttering, at frequent intervals, a harsh and prolonged ery like $K \bar{a}-\bar{a}-\bar{a}-\bar{a} h, K \bar{a}-\bar{a}-\bar{a}-\bar{a} h$ ! It was sitting about 20 feet from the ground and allowed me to approach quite closely, showing no sign of alarm. Apparently not very common as I saw no other specimens. Collected at the Hacienda El Molino, Jalisco, June 11.

Iris rich brown ; cere and eyelids lemon-yellow; bill plumbeous, darker at the tip; gape chrome yellow; tarsus chrome.

\section{Polyborus cheriway (Jacq.).}

Very common in the valleys both in San Luis Potosi and in the State of Jalisco. Often seen in scattered troops of three or four individuals on the ground prowling around in search of dead bodies of small animals or other refuse.

Hacienda Angostura, San Luis Potosi, December 14.

Iris yellow; bill lead-color; cere and throat chrome-yellow; tarsi and toes bright chrome.

\section{Family PELECANIDA.}

94. Pelecanus californicus Ridgw.

Very abundant in the harbor of Guaymas, where specimens were taken in full plumage in latter part of February.

(Color notes of this species have been unfortunately mislaid.)

Family ARDEID A.

95. Ardetta exilis (Gmel.).

Taken at Lake Patzcuaro, December 20.

96. Botaurus lentiginosus (Montag.).

Taken at Lake Patzcuaro, December 20.

97. Tigrisoma cabanisi Heine.

This bird, which is quite common in the streams of the lower part of the State of San Luis Potosi, shares with the land-otter the native name of "perro de agua," or water dog. This incongruous name is said to have been applied to the bird on account of the hoarse barking croak which the creature makes when disturbed.

Male, female and full-grown young were taken on the Rio Verde, at the Hacienda Angostura, December 9 and 15.

Iris, pale chrome; under mandible and cere, pale greenish yellow; throat, king's yellow; tarsi and toes, dusky greenish.

$$
\text { Family IBIDID } A \text {. }
$$

98. Plegadis guarauna (Linn.).

Very common in all marshy places in the central table-land, also found about all small streams and lakes. Taken at Lake Patzcuaro, December 22 . 
Family ANATIDA.

99. Erismatura rubida (Wils.).

Taken near San Luis Potosi, November 14. Common in streams throughout the State.

A flock of ducks were frequently seen as late as the middle of May in the Barranca Ibarra, Jalisco, but they were very shy and no specimens were obtained. From their size I should judge that they were some species of Anas. Several species of ducks were common on Lake Chapala during the winter months the most abundant being Dafila acuta, Aythya collaris, Anas boschas and obscura(?). Grebes were also abundant and coots thronged the beaches.

\section{Family COLUMBID Æ.}

100. Columba fasciata Say.

Specimens taken in northern Sonora, 32 miles south of Nogales, June 14. Inner portion of iris, pale yellow; outer edge, lilac; eyelids, maroon; bill, dull cadmium; tip, black; tarsi and toes, clear cadmium.

\section{Melopelia leucoptera (Linn.).}

A common species throughout central Mexico, it is much prized by the natives as a pet, and almost every hut shows a cage or two with its mournful occupants, hanging at the door. Its doleful song has been transposed by some poetical genius into the following refrain,-

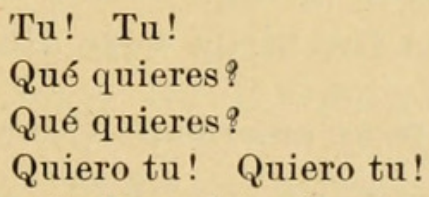

You! you! What do I want? I want (or love) you! I love you!

Fresh colors are as follows: Iris, ochraceous-rufous; cere campanula-blue; tarsi and toes, dull maroon-purple.

102. Scardafella inca (Less.).

An abundant and familiar species everywhere. It has become semidomesticated and may be found at all times about gardens and roadsides. Specimens were taken at San Luis Potosi and Guadalajara in October, December, and June. Iris, dull orange; bill, dusky, tarsi and toes, pale flesh color.

\section{Engyptila, sp.}

Apparently not a common bird in the regions visited. A specimen was shot in the Barranca Veltran March 24. 


\section{$2 \mathrm{BHL}$ Biodiversity Heritage Library}

Jouy, P L. 1894. "Notes on birds of central Mexico, with descriptions of forms believed to be new." Proceedings of the United States National Museum 16(975), 771-791. https://doi.org/10.5479/si.00963801.975.771.

View This Item Online: https://www.biodiversitylibrary.org/item/53716

DOI: https://doi.org/10.5479/si.00963801.975.771

Permalink: https://www.biodiversitylibrary.org/partpdf/53083

\section{Holding Institution}

Smithsonian Libraries

\section{Sponsored by}

Smithsonian

\section{Copyright \& Reuse}

Copyright Status: Public domain. The BHL considers that this work is no longer under copyright protection.

This document was created from content at the Biodiversity Heritage Library, the world's largest open access digital library for biodiversity literature and archives. Visit BHL at https://www.biodiversitylibrary.org. 